Elsevier required licence: (C) <2019>. This manuscript version is made available under the CC-BY-NCND 4.0 license http://creativecommons.org/licenses/by-nc-nd/4.0/

The definitive publisher version is available online at

[https://www.sciencedirect.com/science/article/pii/S0045653518322604?via\%3Dihub] 


\section{Acid mine drainage treatment by integrated submerged membrane}

distillation -sorption system

Seongchul Ryu ${ }^{\mathrm{a}}$, Gayathri Naidu ${ }^{\mathrm{a}}$, Md. Abu Hasan Johir ${ }^{\mathrm{a}}$, Sanghyun Jeong ${ }^{\mathrm{b}}$, Saravanamuthu

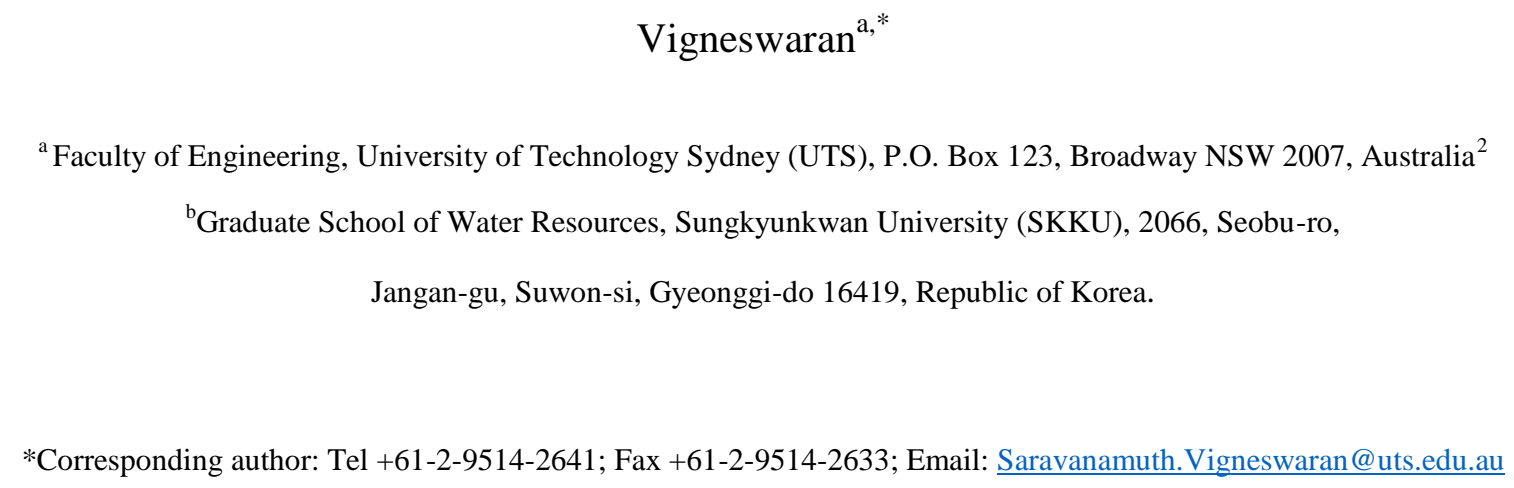

\section{Abstract}

Acid mine drainage (AMD), an acidic effluent characterized by high concentrations of sulfate and heavy metals, is an environmental and economic concern. The performance of an integrated submerged direct contact membrane distillation (DCMD) - zeolite sorption system for AMD treatment was evaluated. The results showed that modified (heat treated) zeolite achieved $26-30 \%$ higher removal of heavy metals compared to natural untreated zeolite. Heavy metal sorption by heat treated zeolite followed the order of $\mathrm{Fe}>\mathrm{Al}>\mathrm{Zn}>\mathrm{Cu}>\mathrm{Ni}$ and the data fitted well to Langmuir and pseudo second order kinetics model. Slight $\mathrm{pH}$ adjustment from 2 to 4 significantly increased $\mathrm{Fe}$ and $\mathrm{Al}$ removal rate (close to $100 \%$ ) due to a combination of sorption and partial precipitation. An integrated system of submerged DCMD with zeolite for AMD treatment enabled to achieve 50\% water recovery in $30 \mathrm{~h}$. The integrated system provided a favourable condition for zeolite to be used in powder form with full contact time in a storing tank. Likewise, heavy metal removal from AMD by zeolite, specifically $\mathrm{Fe}$ and $\mathrm{Al}$, mitigated membrane fouling on the surface of the hollow fiber 
submerged membrane. The integrated system produced high quality fresh water while concentrating sulfuric acid and valuable heavy metals $(\mathrm{Cu}, \mathrm{Zn}$ and $\mathrm{Ni})$.

\section{Keywords}

Acid mine drainage, Heavy metal, Integrated process, Submerged membrane distillation, Sorption, Zeolite

\section{Introduction}

The formation of acid mine drainage (AMD) is a natural process attributed to the oxidation of sulfide minerals such as pyrites (Kalin et al., 2006; Mosley et al., 2018). Active and abandoned mines intensifies the formation of AMD due to open pits, mining waste rock, structures and tailings that are exposed to water, air and bacterial activity (Kalin et al., 2006; Mosley et al., 2018; Tolonen et al., 2014). AMD is characterized by low pH and high concentration of sulfate, as well as high concentrations of heavy metals activity (Kalin et al., 2006; Mosley et al., 2018; Tolonen et al., 2014). Nearby water streams are susceptible to AMD infiltration, resulting in discoloration of streams, decrease in $\mathrm{pH}$ and accumulation of heavy metals. In Australia, there are a significantly high amount of abandoned mines (more than 50,000 mines) compared to actively operating mines (around 380 mines) (Parbhakar-Fox et al., 2014; Unger et al., 2012). An estimated total land area of $215,000 \mathrm{~km}^{2}$ around coastlines and inlands in Australia contain acid sulfate soils attributed to AMD (Fitzpatrick et al., 2009). The long-term impact of AMD contaminant on aquatic organisms, plant growth and human health is a significant concern, which necessitates AMD treatment (Mosley et al., 2018). 
51 Conventionally, AMD is treated by using alkaline neutralizing chemicals such as caustic soda or limestone, to elevate the $\mathrm{pH}$ and precipitate metals (Tolonen et al., 2014). Although efficient, precipitation results in large volumes of sludge containing heavy metals that require safe disposal (Marcello et al., 2008). Various other active and passive remediation approaches such as bioremediation, wetlands, adsorption, phytoremediation are also used to treat AMD (Zhang, 2011; Vasquez et al., 2016; Crane and Sapsford, 2018). In this regard, the uptake of heavy metals by low-cost sorbents are especially promising as a cost effective treatment method for AMD.

In Australia, naturally occurring zeolites are available in large quantities at relatively low cost (Santiago et al., 2016). A significant advantage of zeolite is its tendency to adsorb cations. The ion exchange affinity of natural and synthetic zeolites for metal extraction from wastewater solution including acid mine drainage has been described by previous studies (Motsi et al., 2009; Rios et al., 2008; Wingenfelder et al., 2005). Castle Mountain, Australia produces a natural clinoptilolites (An et al., 2011). The uptake of heavy metals from AMD by Australian natural clinoptilolites may offer a low cost treatment option for AMD. In this regard, a number of approaches are used to enhance the sorption capacity of natural zeolite such as heat treatment, surface and chemical modification (Motsi et al., 2009; Taffarel and Rubio, 2010; Turner et al., 2000). Motsi et al. (2009) reported on the enhanced heavy metal removal of natural zeolite upon microwave and furnace heat treatment. Heat treatment for enhancing the performance of natural zeolite is especially attractive given that it requires no additional chemicals and complex processes.

Compared to the conventional approach of treat and discharge, more focus is now being placed on achieving water reuse for AMD treatment. Therefore, membrane technologies are 
becoming favourable AMD treatment options. This is especially reflected by the increase in the implementation of membrane treatment processes such as reverse osmosis (RO) and nanofiltration (NF) at actual mining sites (Aguiar et al., 2016; Ambiado et al., 2017). Although NF and RO do meet good water reuse standards, membrane fouling and low recovery rate remain challenges. In view of this, recent studies are exploring the potential of alternative membrane processes such as electrodialysis, and forward osmosis for AMD treatment. For instance, Martí-Calatayud et al. (2014) reported on the promising capacity of electrodialysis for treating AMD but inorganic membrane precipitation by metals such as iron was a significant drawback. Similarly, Vital et al. (2018) explored the feasibility of using forward osmosis with $\mathrm{NaCl}$ as a draw solution for treating AMD. Although FO was able to achieve more than $98 \%$ rejection of ions, the phenomenon of reverse salt flux and dilution of draw solution were major limitations.

Alternatively, membrane distillation (MD), a thermal based membrane process, has shown promising potential for treating acid based wastewater from metal pickling industry (Tomaszewska et al., 2001), and concentrating various types of acid including sulfuric acid from AMD (Kesieme et al., 2012; Tomaszewska and Mientka, 2009). The suitability of MD for concentrating acid is attributed to its capacity to achieve high rejection of non-volatile compounds with up to $90 \%$ water recovery ratio, producing good quality fresh water by using vapor pressure difference as its driving force. Additionally, MD requires minimal electrical energy requirement compared to pressure operated systems such as RO and NF while the low thermal requirement $\left(40-80{ }^{\circ} \mathrm{C}\right)$ can be met by alternative thermal sources such as solar or waste heat (Khayet, 2013). MD offers a promising potential for achieving near zero liquid discharge for small scale treatment such as AMD (Naidu et al., 2014; Naidu et al., 2017). 
Direct contact MD (DCMD) is the most studied MD configuration due to its simplicity 102 (Naidu et al., 2017). A number of operating approaches has been considered to improve the 103 performance of DCMD. One such approach is using submerged DCMD, in which the 104 membrane module is submerged directly into the feed solution tank (Choi et al., 2017). This 105 configuration enables to achieve a compact system with reduced heat losses, attributed to the 106 elimination of feed recirculation and reheating. Another promising aspect of submerged 107 DCMD is its flexibility to be used as an integrated single system such as a submerged membrane-sorption system (Naidu et al., 2018). The application of submerged DCMD as an integrated single system for heavy metal removal while simultaneously producing fresh water 110 and concentrating AMD has yet to be explored.

112 The focus of this study is to evaluate the performance of (i) Australia's natural and modified 113 (heat treated) zeolite for heavy metal removal from AMD (ii) submerged DCMD for 114 producing water for reuse from AMD and (iii) integrated submerged DCMD - sorption 115 system for simultaneously removing heavy metals and producing water for reuse from AMD. 


\section{Material and methods}

\subsection{Acid mine drainage solution}

A model acid mine drainage (AMD) solution was prepared based on AMD characteristics from actual mining sites reported by previous studies (Caraballo et al., 2009; Contreras et al., 2015) (Table 1). The model solution was prepared by dissolving analytical grade $\mathrm{CaSO}_{4}$,

$122 \mathrm{MgSO}_{4} \cdot\left(3 \mathrm{H}_{2} \mathrm{O}\right), \quad \mathrm{NaOH}, \quad \mathrm{FeO}(\mathrm{OH}), \quad \mathrm{Fe}\left(\mathrm{SO}_{4}\right) \cdot 7 \mathrm{H}_{2} \mathrm{O}, \quad \mathrm{ZnSO}_{4} \cdot 7 \mathrm{H}_{2} \mathrm{O}, \quad \mathrm{CuSO}_{4} \cdot 5 \mathrm{H}_{2} \mathrm{O}$, $\mathrm{Al}_{2}\left(\mathrm{SO}_{4}\right)_{3} \cdot 18 \mathrm{H}_{2} \mathrm{O}$ and $\mathrm{Ni}\left(\mathrm{NO}_{3}\right)_{2} \cdot 6 \mathrm{H}_{2} \mathrm{O}$ (Sigma-Aldrich and Thermo Fisher Scientific) in Milli-Q water. The solution $\mathrm{pH}$ was adjusted using $10 \mathrm{M}$ of concentrated sulfuric acid $\left(\mathrm{H}_{2} \mathrm{SO}_{4}\right)(10 \mathrm{M})$. The $\mathrm{pH}$ and total dissolved solids (TDS) contents of the AMD solution was detected by a portable multimeter (HQ40d, HACH, US). Inductively coupled plasma-mass spectrometry (ICP-MS, Agilent 7900, US) was used to analyse the cation value in AMD.

Sulfate concentration was measured by ion chromatography (IC, 790 Personal IC, Metrohm, Switzerland).

Table 1 Characteristics of synthetic AMD

\begin{tabular}{lll}
\hline Parameters & Values & Unit \\
\hline $\mathrm{pH}$ & $2.0 \pm 0.2$ & - \\
$\mathrm{TDS}$ & 6.35 & $\mathrm{~g} / \mathrm{L}$ \\
$\mathrm{Ca}$ & 170 & $\mathrm{mg} / \mathrm{L}$ \\
$\mathrm{Mg}$ & 220 & $\mathrm{mg} / \mathrm{L}$ \\
$\mathrm{Na}$ & 50 & $\mathrm{mg} / \mathrm{L}$ \\
$\mathrm{Fe}$ & 340 & $\mathrm{mg} / \mathrm{L}$ \\
$\mathrm{Zn}$ & 120 & $\mathrm{mg} / \mathrm{L}$ \\
$\mathrm{Cu}$ & 90 & $\mathrm{mg} / \mathrm{L}$ \\
$\mathrm{Al}$ & 150 & $\mathrm{mg} / \mathrm{L}$ \\
\hline
\end{tabular}




\begin{tabular}{lcc}
\hline $\mathrm{Ni}$ & 3.5 & $\mathrm{mg} / \mathrm{L}$ \\
$\mathrm{SO}_{4}$ & 4.3 & $\mathrm{~g} / \mathrm{L}$
\end{tabular}

132

133

134

135

151 Table 2 Natural zeolite chemical contents

\begin{tabular}{lc}
\hline Chemical content & wt.\% \\
\hline $\mathrm{SiO}_{2}$ & 71.81 \\
$\mathrm{Al}_{2} \mathrm{O}_{3}$ & 12.10 \\
\hline
\end{tabular}

\subsection{Zeolite}

\subsubsection{Natural zeolite} percentages of quartz and mordenite $(\sim 15 \mathrm{wt} \%)$.

\subsubsection{Heat treated zeolite} tight containers in a desiccator.

The performance of natural Australian zeolite sorbent in powder form (particle size $<75 \mu \mathrm{m}$ ) for heavy metal removal from AMD solution was evaluated. The mineral composition (as supplied by Castle Mountain, NSW, Australia) is listed in Table 2. This natural zeolite with a bulk density of is $2.7 \mathrm{~g} / \mathrm{cm}^{3}$ is mainly encompassed of clinoptilolite ( $\left.85 \mathrm{wt} \%\right)$ with minor

Heat treatment method was used to potentially enhance the performance of natural zeolite (Motsi et al., 2009; Turner et al., 2000). Heat treatment was chosen as it requires no additional chemicals and complex modification process. Heat treatment was carried out by placing an appropriate amount of powder form natural zeolite in a ceramic dish. The ceramic dish was then placed into preheated air atmosphere muffle furnace (Labec Laboratory Pty Ltd, NSW, Australia). Heat treatment was carried out at four different temperatures of 300, 400, 500 and $600{ }^{\circ} \mathrm{C}$ for $24 \mathrm{~h}$. Upon heat treatment, the zeolite sorbents were stored in air 


\begin{tabular}{ll}
\hline $\mathrm{CaO}$ & 2.60 \\
$\mathrm{Na}_{2} \mathrm{O}$ & 2.33 \\
$\mathrm{Fe}_{2} \mathrm{O}_{3}$ & 1.14 \\
$\mathrm{~K}_{2} \mathrm{O}$ & 0.90 \\
$\mathrm{MgO}$ & 0.65 \\
$\mathrm{TiO}_{2}$ & 0.22 \\
$\mathrm{MnO}$ & 0.03 \\
$\mathrm{SrO}$ & 0.22 \\
$\mathrm{P}_{2} \mathrm{O}_{5}$ & $<0.01$ \\
\hline
\end{tabular}

152

\subsection{Zeolite characteristics}

\subsubsection{Surface area and pore width distribution}

Nitrogen adsorption test was used to determine the Brunauer-Emmett-Teller (BET) specific surface area and the Barrett-Joyner-Halenda $(\mathrm{BJH})$ pore width distribution of the natural and heat treated zeolite samples. Nitrogen adsorption test was measured with a Micrometrics ASAP $2020 \mathrm{HD}$ analyzer using low temperature, per the procedure of ISO 9277 and ISO 15901-2.

\subsubsection{Crystal structure}

162 X-ray diffraction (XRD) (Siemens D5000 diffractometer operating with $\mathrm{Cu}-\mathrm{K} \alpha$ radiation source) was used to detect the crystal structure of zeolite (natural and heat treated samples) in powder form. A rotating sample stage was used to scan the samples at $2 \theta$ angular range of 10 to $80^{\circ}$ in room temperature.

\subsubsection{Surface morphology and element contents}


A scanning electron microscopy (SEM) ((Zeiss Supra 55VP Field Emission) was used to analyse the zeolite surface characteristics (before and upon sorption). The SEM was integrated with energy dispersive X-ray spectroscopy (EDX) (15kV accelerating voltage) in order to analyse the element contents in zeolite.

\subsubsection{Influence of $\mathrm{pH}$ and surface charge}

The $\mathrm{pH}$ influence on heavy metal sorption by zeolite was determined by varying the $\mathrm{pH}$ of AMD solution from 2 to 5 . The initial $\mathrm{pH}$ of the solution was adjusted using $10 \mathrm{M}^{\text {of }} \mathrm{H}_{2} \mathrm{SO}_{4}$ and $\mathrm{NaOH}$. Zeolite $(10 \mathrm{~g} / \mathrm{L})$ was placed in beakers with $100 \mathrm{ml}$ AMD solution. The $\mathrm{pH}$ of the initial solutions were varied. The flasks were kept suspended for $12 \mathrm{~h}$ in a shaker $(120 \mathrm{rpm})$ at ambient temperature $\left(24{ }^{\circ} \mathrm{C}\right)$. The initial and final $\mathrm{pH}$ of the AMD solution in the beakers were recorded.

Zeolite surface charge was determined using zeta potential measurement. For this purpose, zeolite $(1 \mathrm{~g} / \mathrm{L})$ placed in beakers with $100 \mathrm{ml}$ AMD solution. The $\mathrm{pH}$ of the initial solutions were varied from $1-9$. The flasks were kept suspended for $12 \mathrm{~h}$ in a shaker $(120 \mathrm{rpm})$ at room temperature $\left(24 \pm 1{ }^{\circ} \mathrm{C}\right.$ ). Zetasizer (nano instrument ZS Zen3600, UK) was used to analyse the zeolite surface charge.

\subsection{Sorption study}

\subsubsection{Equilibrium}

For equilibrium sorption in batch study, zeolite with varying doses ranging from $0.10-15$ g/L was added to beakers containing $100 \mathrm{ml}$ of AMD solutions. The beakers were kept suspended for $12 \mathrm{~h}$ in a shaker $(120 \mathrm{rpm})$ at room temperature $\left(24 \pm 1{ }^{\circ} \mathrm{C}\right)$ to achieve equilibrium sorption. The solution $\mathrm{pH}$ was maintained at $2.0 \pm 0.2$ to evaluate the 
performance of zeolite in actual acidic AMD condition and to ensure no precipitation of 194 heavy metal occurred at increased $\mathrm{pH}$. The concentration of heavy metals ( $\mathrm{Fe}, \mathrm{Al}, \mathrm{Zn}, \mathrm{Cu}$ and

195

196

197

198

199

200

201

202

203

204

205

206 Langmuir isotherm: $Q_{e}=\frac{Q_{m} b C_{e}}{1+b C_{e}}$

207

208 Freundlich isotherm: $Q_{e}=K C_{e}{ }^{1 / n}$

$Q_{e}=\frac{V\left(C_{i}-C_{e}\right)}{M}$ data as below:

Ni) in AMD solution before and after sorption was analysed using ICP-MS. $Q_{e}(\mathrm{mg} / \mathrm{g})$, equilibrium sorption capacity, was represented by Eq. (1):

$V(L)=$ solution volume and $M(g)=$ sorbent mass. $C_{i}$ and $C_{e}$ are the concentrations of the heavy metals at initial and equilibrium, respectively.

Isotherm models (Langmuir and Freundlich) were used to analyse the equilibrium sorption

209

210 in which, $\mathrm{Q}_{\mathrm{m}}(\mathrm{mg} / \mathrm{g})$ is the sorption at maximum capacity and $\mathrm{b}(\mathrm{L} / \mathrm{mg})$ is the Langmuir

211 constant in relation to the affinity of site binding. $K\left(g^{1-n} L^{n} g^{-1}\right)$ is Freundlich constant which 212 relates to the affinity of the sorption and $1 / \mathrm{n}$ is a dimensionless parameter related to surface 213 heterogeneity.

\subsubsection{Kinetics}


Sorption kinetics was conducted in beakers containing AMD solution (100 ml) and zeolite at

217 a dose of $10 \mathrm{~g} / \mathrm{L}$. The solution $\mathrm{pH}$ was maintained at $2.0 \pm 0.2$. The beakers were kept suspended in a shaker $(120 \mathrm{rpm})$ at room temperature $\left(24 \pm 1^{\circ} \mathrm{C}\right)$. At varying time from 0.08 $\mathrm{h}$ up to $24 \mathrm{~h}$, the solutions in the beaker was collected and the metal contents were measured. The kinetic sorption data were computed using kinetic models (pseudo-first and second order) as presented by Eq. (4) and (5):

222

223 Pseudo first order: $\frac{d Q_{t}}{d t}=k_{1}\left(Q_{e}-Q_{t}\right)$

Pseudo second order: $\frac{d Q_{t}}{d t}=k_{2}\left(Q_{e}-Q_{t}\right)^{2}$

The parameters, $k_{1}$ and $k_{2}$, represent the adsorption rate $\left(\mathrm{h}^{-1}\right), Q_{t}$ and $Q_{e}$ are the sorption capacity $(\mathrm{mg} / \mathrm{g})$ at time $\mathrm{t}$ and at equilibrium, respectively.

\subsection{Submerged direct contact membrane distillation}

231

232

A direct contact membrane distillation (DCMD) in submerged condition was used in this study to evaluate the potential of water reuse from AMD solution (Fig. 1). The set-up consists of a double wall feed tank containing AMD solution with a submerged hollow fiber membrane made of polyvinylidene fluoride (PVDF). The membrane was obtained from Econity, Republic of Korea) (Choi et al., 2017; Yao et al., 2018). The membrane pore size, inner and outer diameters, wall thickness, and contact angle are $0.1 \mu \mathrm{m}, 0.7 \mathrm{~mm}$ and $1.2 \mathrm{~mm}$, $250 \mu \mathrm{m}$ and $106 \pm 2^{\circ}$ respectively. The membrane module was made of 18 fibers with $0.2 \mathrm{~m}$ length (active membrane area of $0.0136 \mathrm{~m}^{2}$ ). 
240 The outer wall of the double wall feed tank was circulated with heated water connected to a

241 heating system, enabling to maintain a AMD feed solution temperature of $55.0 \pm 0.5^{\circ} \mathrm{C}$. The

242 permeate solution was maintained at $22 \pm 0.5{ }^{\circ} \mathrm{C}$ using a cooling system. A gear pump was

243 used to circulate the permeate solution at a flow rate of $0.8 \mathrm{~L} / \mathrm{min}$. The increase in permeate

244 volume in the permeate tank was recorded over time using an electronic balance. This is used to compute the permeate flux over time. AMD solution was kept at constant volume of $0.9 \mathrm{~L}$ in the feed tank by replenishing fresh AMD feed solution (from a storage tank) at the same

247 rate as the permeate production rate using a peristaltic pump.

This study evaluated the potential of combining submerged DCMD and zeolite into a single integrated process. For the integrated submerged DCMD-sorption process, AMD solution (pretreated with zeolite) was placed in the feed tank. Meanwhile in the storage tank, zeolite at a predetermined dose was kept suspended at a rate of $120 \mathrm{rpm}$ (as per the batch sorption study) in $1.5 \mathrm{~L}$ of AMD solution. This enabled heavy metal removal by zeolite from AMD solution in the storage tank. A filter holder containing glass fiber membrane (Filtech, Australia) with a pore size of $1.1 \mu \mathrm{m}$ was placed at the top of the holding tank to filter the used zeolite, ensuring only pretreated AMD solution enters the feed tank. 


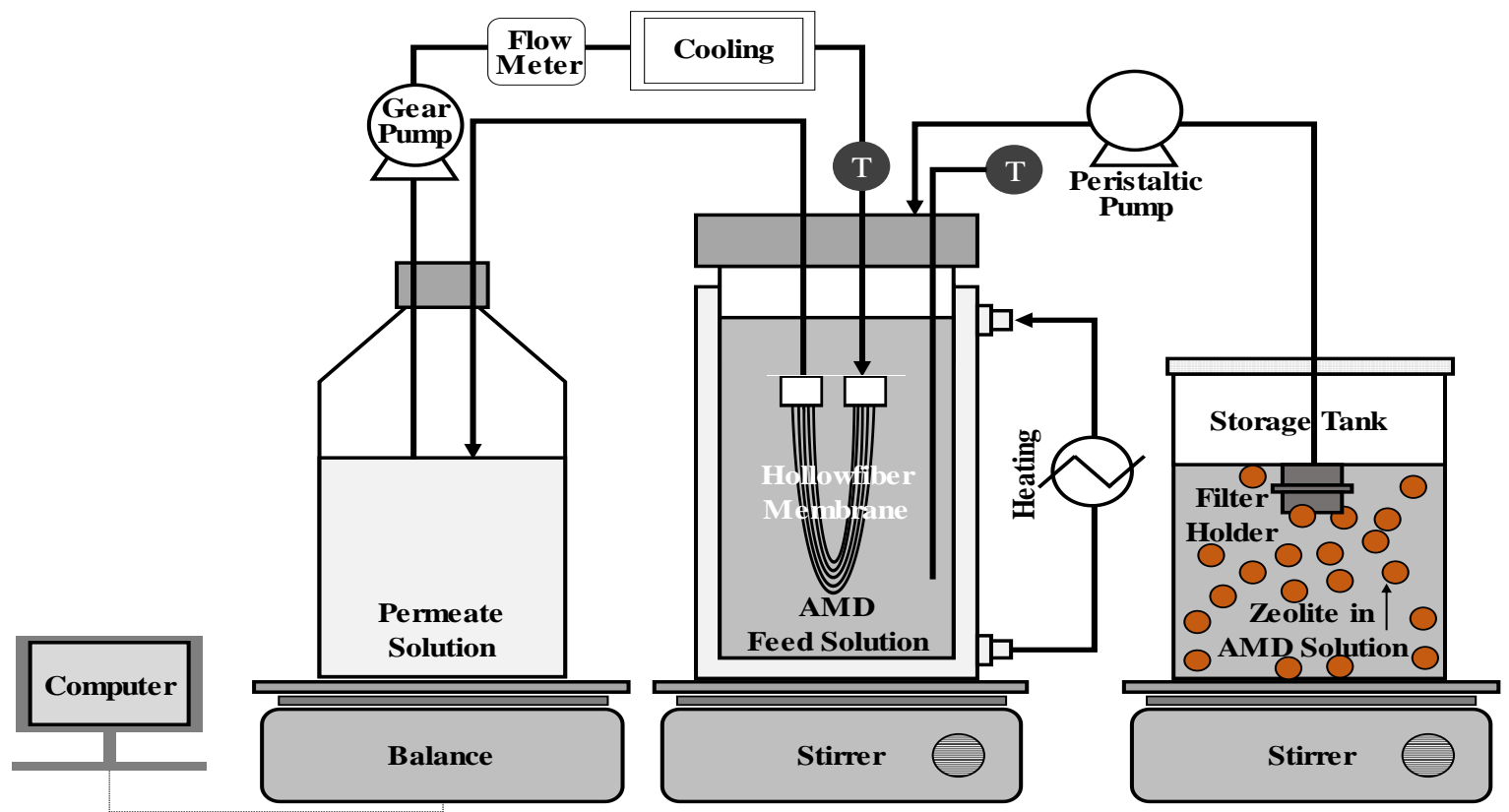

259 Fig. 1. Set-up of integrated submerged DCMD - sorption system

\subsubsection{Membrane analysis}

The morphology and element composition on the surface of the used and virgin membranes were analysed using SEM-EDX at a voltage of $15 \mathrm{kV}$ as per the details mentioned in Section 2.3.3. The hydrophobicity of the virgin and used membranes were evaluated by measuring the water contact angle of the membrane using a goniometer (Theta Lite, Biolin Scientific, Sweden). Measurements were duplicated at different location of the membrane and the average value was used for this study.

\section{Results and discussion}

\subsection{Performance of natural and modified (heat treated) zeolite}

The sorption capacity of natural and modified (heat treated) zeolite was tested for heavy metal removal from AMD. Higher heavy metal removal was achieved with heat treated

272 zeolite compared to natural untreated zeolite (Table 3). The removal of heavy metals 273 increased from $1-12 \%$ with natural zeolite by up to $30-38 \%$ upon heating $\left(500{ }^{\circ} \mathrm{C}\right)$. 
Heating may have removed water on the surface as well as internal channels of the natural zeolite, resulting in vacant channels which enhances heavy metal sorption rate, as reported by previous studies (Ohgushi and Nagae, 2003; Turner et al., 2000). However, heavy metal removal by zeolite minimally improved beyond $500{ }^{\circ} \mathrm{C}$ of heating. This trend could be attributed to characteristics change of zeolite upon heat treatment.

Table 3 Performance of natural and heat treated zeolite with AMD solution (sorbent dose 5.0 $\pm 0.2 \mathrm{~g} / \mathrm{L}, \mathrm{pH} 2.0 \pm 0.2)$.

\begin{tabular}{llllll}
\hline Sorbent type & \multicolumn{5}{c}{ Heavy metal removal (\%) } \\
\cline { 2 - 6 } & $\mathrm{Fe}$ & $\mathrm{Al}$ & $\mathrm{Zn}$ & $\mathrm{Cu}$ & $\mathrm{Ni}$ \\
\hline Natural zeolite & $12.8 \pm 0.9$ & $1.1 \pm 0.2$ & $9.4 \pm 1.4$ & $11.2 \pm 0.7$ & $10.8 \pm 1.1$ \\
Heat treated zeolite & & & & & \\
$300{ }^{\circ} \mathrm{C}$ & $17.9 \pm 1.6$ & $15.7 \pm 0.8$ & $15.6 \pm 2.4$ & $17.1 \pm 1.5$ & $15.9 \pm 2.0$ \\
$400{ }^{\circ} \mathrm{C}$ & $25.3 \pm 2.2$ & $26.1 \pm 1.3$ & $21.1 \pm 2.0$ & $22.8 \pm 1.2$ & $19.7 \pm 1.9$ \\
$500{ }^{\circ} \mathrm{C}$ & $34.9 \pm 2.7$ & $36.3 \pm 2.7$ & $29.3 \pm 2.3$ & $31.3 \pm 1.9$ & $21.1 \pm 1.3$ \\
$600{ }^{\circ} \mathrm{C}$ & $31.0 \pm 2.5$ & $30.8 \pm 2.4$ & $27.0 \pm 2.3$ & $29.1 \pm 2.1$ & $20.0 \pm 2.9$ \\
\hline
\end{tabular}

\subsubsection{Characteristics of zeolite}

\subsubsection{Surface area and pore width distribution}

The surface area (BET) and pore width (BJH) of natural zeolite was $14.5 \mathrm{~m}^{2} / \mathrm{g}$ and $147.59 \AA$. The surface area and pore width of zeolite showed an increasing trend with heat treatment up to $500{ }^{\circ} \mathrm{C}$ (Table 4). This implies that thermal heating contributed towards the activation of zeolite surface and possible removal of water (Akdeniz and Ülkü, 2007; Ohgushi and Nagae, 2005). In turn, metal removal increased (Table 3). On the other hand, the slightly lower surface area and pore width at $600{ }^{\circ} \mathrm{C}$ compared to $500{ }^{\circ} \mathrm{C}$ could explains the minimal changes in heavy metal removal above $500{ }^{\circ} \mathrm{C}$ (Table 3). 
293 The results showed that heat treatment of zeolite at $500{ }^{\circ} \mathrm{C}$ was optimum to enhance its 294 performance. Based on these results, $500{ }^{\circ} \mathrm{C}$ heat treated zeolite in powder form was used for 295 all further experiments.

297 Table 4 Surface area and pore width of natural and heat treated zeolite.

\begin{tabular}{lcc}
\hline Sorbent type & BET Surface area $\left(\mathrm{m}^{2} / \mathrm{g}\right)$ & BJH Pore width $(\AA)$ \\
\hline Natural zeolite & 14.5 & 147.6 \\
Heat treated zeolite & & \\
$300{ }^{\circ} \mathrm{C}$ & 14.8 & 147.5 \\
$400{ }^{\circ} \mathrm{C}$ & 15.0 & 148.2 \\
$500{ }^{\circ} \mathrm{C}$ & 16.2 & 150.9 \\
$600{ }^{\circ} \mathrm{C}$ & 14.9 & 147.9
\end{tabular}

298

299

\subsubsection{Crystal structure}

300 The XDR spectra (Fig. 2) showed similar diffraction pattern for natural and heat treated 301 zeolite. This affirmed that heat treatment did not change the crystal structure. Further, the 302 XRD spectra also established that the natural Australian zeolite used in this study 303 corresponded to that of the structure of clinoptilolite, as reported by previous papers (Nguyen et al., 2015; Naidu et al., 2018). 


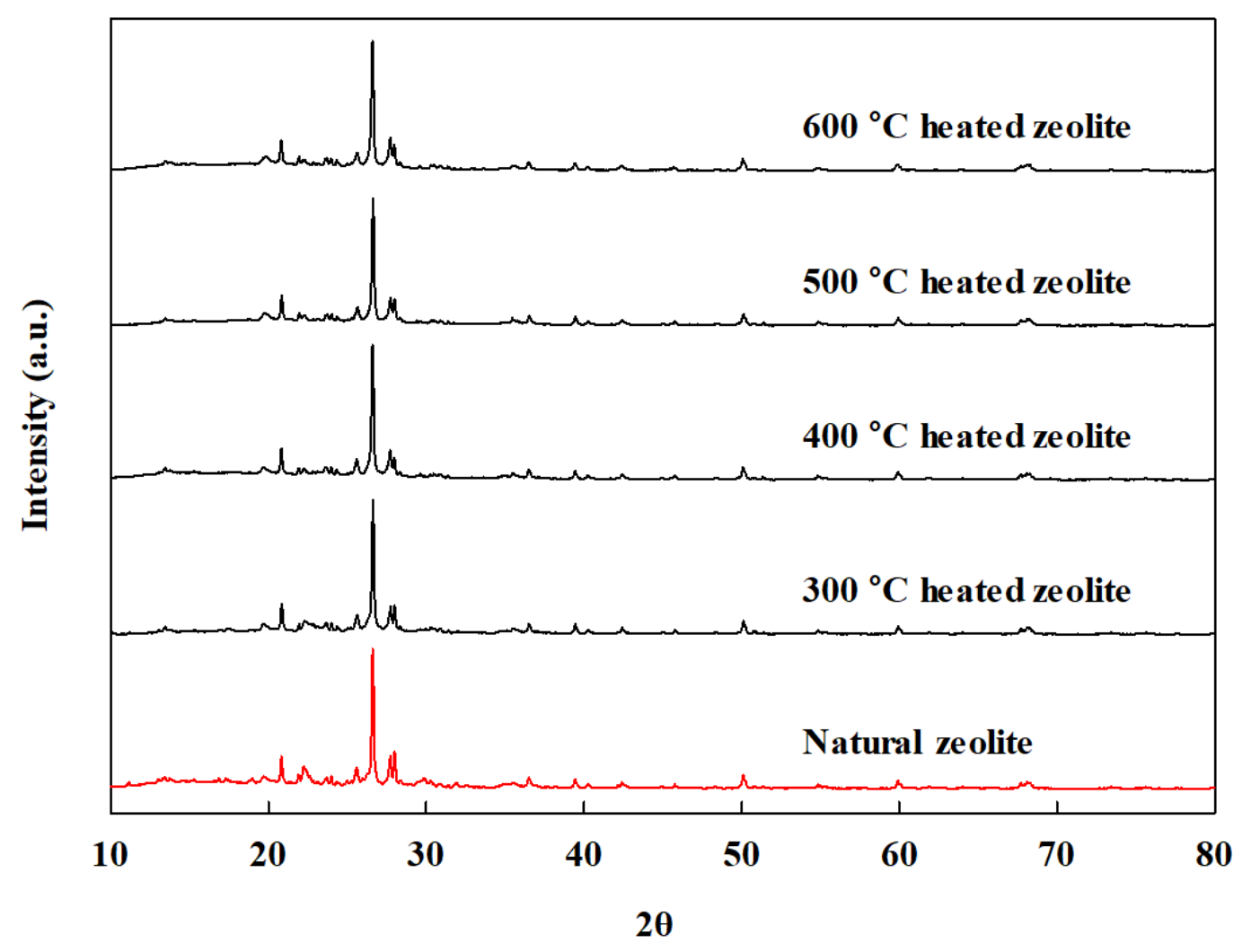

305

Fig. 2. XRD peaks of natural and heat treated zeolite

307

\subsubsection{Surface morphology and element contents}

The SEM images showed the heterogeneous condition of the zeolite (Fig. 3). No significant morphology changes were observed between the natural and heat treated zeolites.

312 The EDX established $\mathrm{Si}, \mathrm{O}, \mathrm{K}, \mathrm{Al}, \mathrm{Mg}, \mathrm{Na}, \mathrm{Fe}$ and $\mathrm{Ca}$ as the main element peaks in all 313 zeolite structure (Fig. 4). The slight decrease of $\mathrm{O}$ atomic content from 67.52 in the natural 314 zeolite to $66.61 \%$ upon heat treatment could be due to the removal of water in the internal 315 channels (Table 5). The EDX analysis of heat treated zeolite (after sorption of heavy metals from $\mathrm{AMD}$ ) showed reduction in $\mathrm{Si}, \mathrm{Na}, \mathrm{Ca}$ and $\mathrm{K}$. Meanwhile the increase of $\mathrm{Fe}$ and $\mathrm{Al}$ as

317 well as the presence of $\mathrm{Cu}, \mathrm{Zn}$ and $\mathrm{Ni}$ establish the heavy metal sorption from AMD. 
(a)

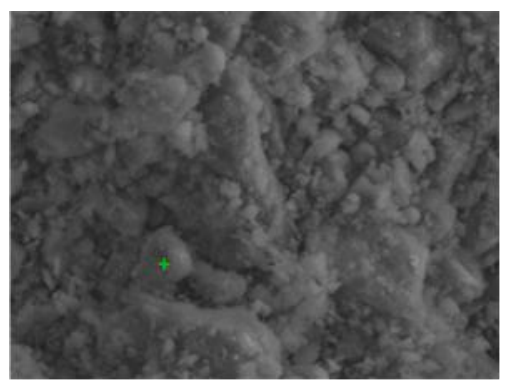

(b)

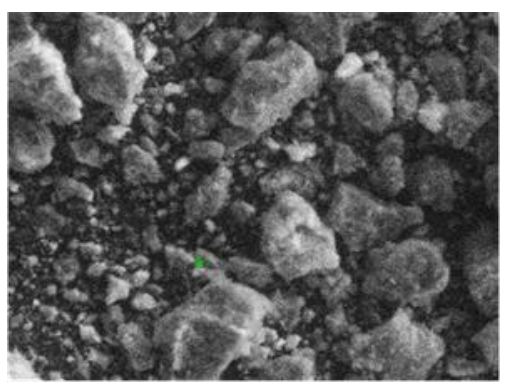

(c)

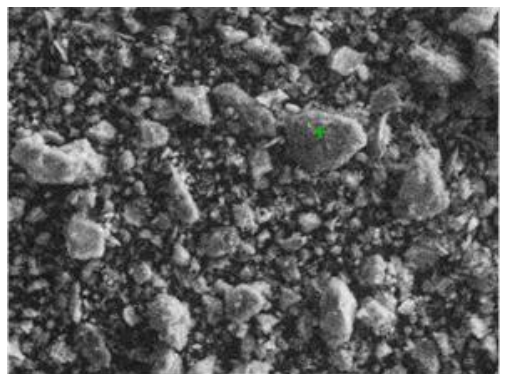

Fig. 3. SEM images of (a) natural untreated zeolite and $500{ }^{\circ} \mathrm{C}$ heat treated zeolite (b) unused/before sorption and (c) after heavy metal sorption

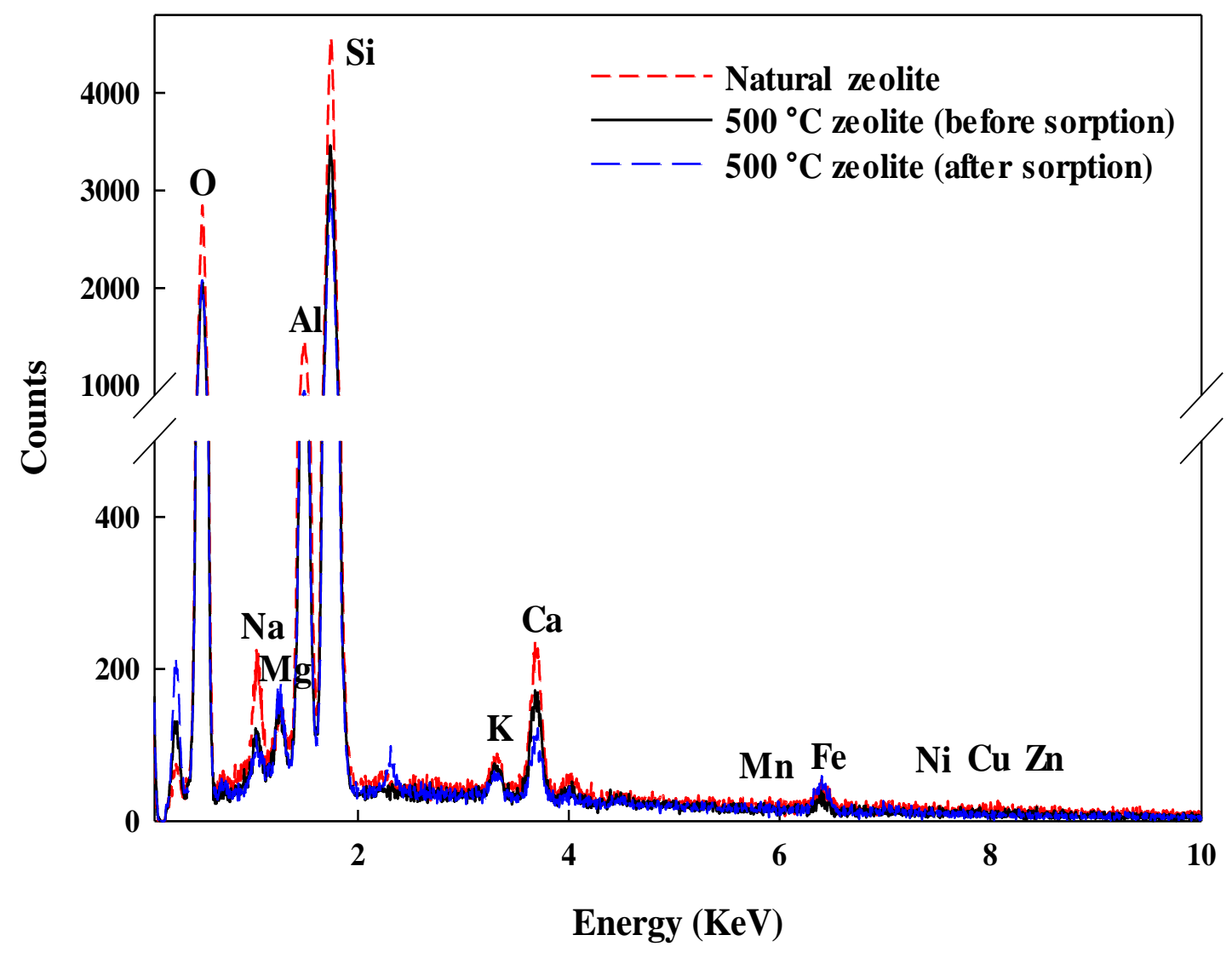

Fig. 4. EDX results of natural and $500{ }^{\circ} \mathrm{C}$ heat treated zeolite (before and after heavy metal sorption). 
325 Table 5 EDX results of natural and $500{ }^{\circ} \mathrm{C}$ heat treated zeolite

\begin{tabular}{llll}
\hline & \multicolumn{3}{c}{$\%$ atomic ratio } \\
\cline { 2 - 4 } & Element & Natural zeolite & $500{ }^{\circ} \mathrm{C}$ heat treated zeolite \\
\cline { 3 - 4 } & & 66.61 & 66.86 \\
\hline $\mathrm{O}$ & 67.52 & 24.68 & 22.56 \\
$\mathrm{Si}$ & 20.95 & 5.25 & 6.65 \\
$\mathrm{Al}$ & 7.61 & 0.61 & 1.27 \\
$\mathrm{Fe}$ & 0.70 & 1.41 & 1.05 \\
$\mathrm{Ca}$ & 1.63 & 0.62 & 0.81 \\
$\mathrm{Mg}$ & 0.27 & 0.30 & 0.25 \\
$\mathrm{~K}$ & 0.28 & 0.54 & 0.39 \\
$\mathrm{Na}$ & 1.06 & & 0.10 \\
$\mathrm{Ni}$ & & & 0.04 \\
$\mathrm{Cu}$ & & & 0.02 \\
$\mathrm{Zn}$ & & & \\
\hline
\end{tabular}

\subsubsection{Equilibrium sorption}

\subsubsection{Isotherm}

329 Heavy metal sorption from AMD solution with $500{ }^{\circ} \mathrm{C}$ heat treated zeolite was computed 330 with Langmuir and Freundlich sorption isotherm (Fig. S1 and Table 6).

332 The data satisfactorily fitted to Langmuir sorption isotherm $\left(\mathrm{R}^{2}=0.87-0.98\right)$ compared to 333 the Freundlich sorption isotherm $\left(\mathrm{R}^{2}=0.79-0.89\right)$. Similarly, a number of studies on zeolite 334 performance for heavy metal removal indicated the suitability of Langmuir isotherm (Motsi et al., 2009; Nguyen et al., 2015; Qiu and Zheng, 2009). Based on the sorption isotherm, heat treated zeolite capacity for heavy metal removal from AMD followed the order of 
$\mathrm{Fe}>\mathrm{Al}>\mathrm{Zn}>\mathrm{Cu}>\mathrm{Ni}$. Poor removal of $\mathrm{Ni}$ by a zeolite could be due to the high stability of its aqueous complex (Mondale et al., 1995).

339

340 The better Langmuir fitting indicated that the sorption sites were homogeneous with 341 monolayer sorption coverage. However, not all the heavy metals achieved a fitting of $\mathrm{R}^{2}$ 342 above 0.95 . This could be attributed to the mixed metals present at different concentrations in 343 AMD (Table 1) resulting in competition of sorption. Nguyen et al (2015) compared the 344 Langmuir fitting of heavy metal removal by zeolite and observed lower Langmuir capacity 345 and fitting for each metal in a mixed metal solution compared to individual metal solution.

347 Table 6 Isotherm data (Langmuir and Freundlich) for heavy metal sorption from AMD 348 solution at $\mathrm{pH} 2.0 \pm 0.2$ using $500{ }^{\circ} \mathrm{C}$ heat treated zeolite.

\begin{tabular}{lllllll}
\hline Heavy metal & \multicolumn{3}{c}{ Langmuir } & \multicolumn{3}{c}{ Freundlich } \\
\cline { 2 - 7 } & $\mathrm{Q}_{\max }$ & $\mathrm{K}_{\mathrm{L}}$ & $\mathrm{R}^{2}$ & $\mathrm{n}$ & $\mathrm{K}_{\mathrm{F}}$ & $\mathrm{R}^{2}$ \\
& $(\mathrm{mg} / \mathrm{g})$ & $(\mathrm{L} / \mathrm{mg})$ & & & $(\mathrm{mg} / \mathrm{g})(\mathrm{L} / \mathrm{mg})^{1 / \mathrm{n}}$ \\
\hline $\mathrm{Fe}$ & 62.11 & 0.031 & 0.97 & 3.20 & 9.73 & 0.89 \\
$\mathrm{Al}$ & 44.64 & 0.072 & 0.90 & 1.40 & 1.34 & 0.83 \\
$\mathrm{Zn}$ & 39.06 & 0.114 & 0.98 & 3.65 & 10.38 & 0.85 \\
$\mathrm{Cu}$ & 36.10 & 0.075 & 0.95 & 2.67 & 6.11 & 0.81 \\
$\mathrm{Ni}$ & 1.09 & 1.326 & 0.91 & 1.96 & 0.62 & 0.90
\end{tabular}




\subsubsection{Kinetics}

352 Sorption of all heavy metals from AMD solution by $500{ }^{\circ} \mathrm{C}$ heat treated zeolite increased with time up to 12 hours and reached equilibrium at approximately $20 \mathrm{~h}$. From the uptake curves in Fig. S2, it is evident that the rate of sorption was initially fast (within $4 \mathrm{~h}$ ) and was gradually slow when approaching equilibrium. Kinetic experiment of heavy metal sorption was fitted to pseudo first and second order models (Fig. S2 and Table 7). The experimental data was well matched to both pseudo first order $\left(\mathrm{R}^{2}=0.94-0.99\right)$ and pseudo second order $\left(\mathrm{R}^{2}=0.99\right)$. The calculated $\mathrm{Q}_{\mathrm{e}}$ in both cases were almost similar to the experimental values of Qe.

Table 7 Pseudo first and second order kinetic parameters for heavy metal sorption from

AMD solution at $\mathrm{pH} 2.0 \pm 0.2 \mathrm{using} 500{ }^{\circ} \mathrm{C}$ heat treated zeolite $($ dose $=10 \pm 0.2 \mathrm{~g} / \mathrm{L})$

\begin{tabular}{|c|c|c|c|c|c|c|c|}
\hline \multirow{2}{*}{$\begin{array}{l}\text { Heavy } \\
\text { metals }\end{array}$} & \multirow{2}{*}{$\begin{array}{l}\mathrm{Q}_{\mathrm{e}}(\exp ) \\
(\mathrm{mg} / \mathrm{g})\end{array}$} & \multicolumn{3}{|c|}{ Pseudo first order } & \multicolumn{3}{|c|}{ Pseudo second order } \\
\hline & & $\begin{array}{l}\mathrm{Q}_{\mathrm{e}}(\mathrm{pre}) \\
(\mathrm{mg} / \mathrm{g})\end{array}$ & $\begin{array}{l}\mathrm{k}_{1} \\
\left(\mathrm{hr}^{-1}\right)\end{array}$ & $\mathrm{R}^{2}$ & $\begin{array}{l}\mathrm{Q}_{\mathrm{e}}(\mathrm{pre}) \\
(\mathrm{mg} / \mathrm{g})\end{array}$ & $\begin{array}{l}\mathrm{k}_{2} \\
(\mathrm{~g} / \mathrm{mg} / \mathrm{hr})\end{array}$ & $\mathrm{R}^{2}$ \\
\hline $\mathrm{Fe}$ & 11.95 & 11.73 & 1.45 & 0.98 & 12.87 & 0.04 & 0.99 \\
\hline $\mathrm{Al}$ & 6.07 & 6.11 & 2.06 & 0.99 & 6.27 & 0.20 & 0.99 \\
\hline $\mathrm{Zn}$ & 3.89 & 3.65 & 1.48 & 0.94 & 4.20 & 0.11 & 0.99 \\
\hline $\mathrm{Cu}$ & 3.15 & 2.98 & 1.57 & 0.95 & 3.36 & 0.16 & 0.99 \\
\hline $\mathrm{Ni}$ & 0.11 & 0.10 & 1.55 & 0.95 & 0.11 & 5.17 & 0.99 \\
\hline
\end{tabular}

\subsubsection{Influence of sorbent dose and $\mathrm{pH}$}

Increased heavy metal removal was observed with higher zeolite dose (Fig. 5a). The reducing trend of $\mathrm{Al}$ removal, especially above $10 \mathrm{~g} / \mathrm{L}$ zeolite may be attributed to Al leaching out from the zeolite structure that contain around $12 \mathrm{wt} \% \mathrm{Al}$ as $\mathrm{Al}_{2} \mathrm{O}_{3}$ (Table 1). 


\subsubsection{Ion exchange mechanism}

370 Above zeolite dose of $10 \mathrm{~g} / \mathrm{L}$ onwards, insignificant changes in heavy metal removal was observed. This is due to the decline in the remaining ion concentration in solution with increasing sorbent dose (Al-Haj and Ribhi, 1997). The uptake of heavy metal cations by zeolite has been well established as an exchange mechanism between the cations present in the solution and cations in the zeolite framework, mainly $\mathrm{Na}$ and $\mathrm{Ca}$ (Nguyen et al., 2015; Qiu and Zheng, 2009). The ion exchange mechanism suggest that zeolite may be more selective to monovalent cations. In this scenario, AMD solution ( $\mathrm{pH}$ 2) contain high $\mathrm{H}$ ions and zeolite may preferentially adsorb monovalent $\mathrm{H}$ ions from the solution to divalent heavy metals (Sprynskyy et al., 2006). This could also explain the increase in the $\mathrm{pH}$ of AMD solution from 2.0 to 2.4 upon sorption. Thus, even as the dose of zeolite was increased, heavy metal removal rate remained low in the range of 35 to $40 \%$.

\subsubsection{Electrostatic sorption}

Apart from the ion exchange mechanism, electrostatic sorption, which is the attraction of positively charged metal cations towards negatively charged zeolite surfaces, play an important role in influencing the uptake of heavy metals. Based on the zeta potential analysis, the zeolite surface charge showed a trend of increasing negativity from $-11 \mathrm{mV}$ to $-30 \mathrm{mV}$ as the $\mathrm{pH}$ of the solution was increased from 1 to 9 (Fig. 5b). Previous studies on natural zeolite characteristics reported similar observations of higher negative surface charge as the solution pH was increased (Englert and Rubio, 2005; Nguyen et al., 2015). Increased negative surface charge of zeolite enhances the sorption tendency onto cation metals through electrostatic sorption (outer sphere mechanism). The results of the zeta potential indicated the significant role of $\mathrm{pH}$ for improving metal removal from AMD. 


\subsubsection{Partial precipitation}

395

396

397

400

401

402

403

404

405

406

407

408

409

410

411

412

413

414

415

In this study, a $\mathrm{pH}$ increase from 2 to 5, significantly increased the removal of Fe and $\mathrm{Al}$ by close to $100 \%$ (Fig. 6). Previous AMD studies have highlighted that, at higher $\mathrm{pH}$, removal of $\mathrm{Fe}$ and $\mathrm{Al}$ is attributed to the combination of sorption and partial precipitation (Motsi et al., 2009; Wingenfelder et al., 2005). The high precipitation affinity of $\mathrm{Fe}$ and $\mathrm{Al}$ is due to the low solubility limit of both these metals at $\mathrm{pH}$ above 4 .

Meanwhile, varying the $\mathrm{pH}$ from 2 to 5 only marginally improved the removal rate of $\mathrm{Zn}, \mathrm{Cu}$, and $\mathrm{Ni}$. This result was contrary to a number of zeolite studies that reported on the increase in heavy metal removal rate at higher pH (Alvarez-Ayuso et al., 2003; Moreno et al., 2001; Motsi et al., 2009). Apart from heavy metals, the AMD solution used in this study contained $\mathrm{Na}$ and $\mathrm{Ca}$ that could have played a competitive role in minimizing the $\mathrm{pH}$ effect. Similarly, Wingenfelder et al ( 2005) reported on the poorer removal of heavy metals namely Cd and Zn in the presence of $\mathrm{Ca}$.

Overall the results showed that modified $\left(500{ }^{\circ} \mathrm{C}\right.$ heat treated) zeolite in powder form enabled to remove heavy metals from AMD attributed to a combination of ion exchange, electrostatic sorption and partial precipitation. Nevertheless, it is a challenge to use the powdered form zeolite in ion exchange filter columns (Naidu et al., 2018). For this purpose, the potential of an integrated system, submerged DCMD with zeolite was evaluated in the subsequent section. 

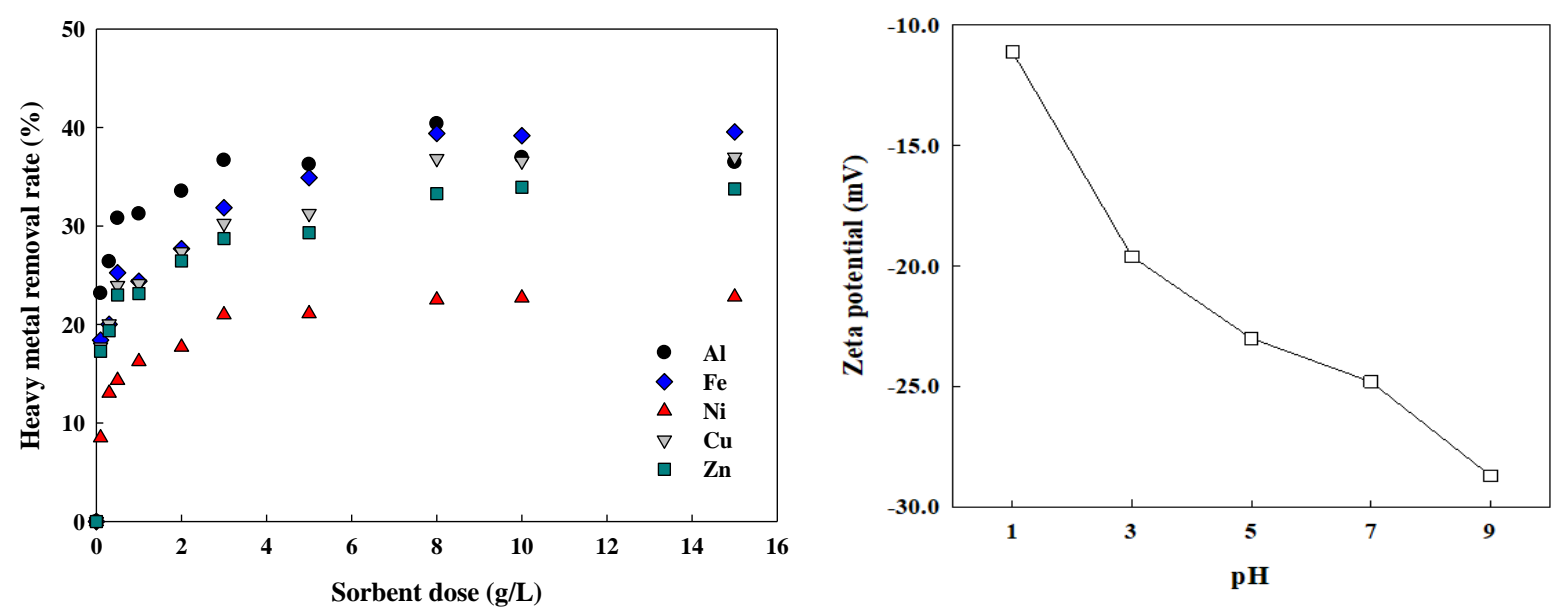

416 Fig. 5. $500{ }^{\circ} \mathrm{C}$ heat treated zeolite (a) heavy metal removal as a function of sorbent dose $(\mathrm{pH}$

$4172.0 \pm 0.2)\left(\right.$ b) zeta potential as a function of $\mathrm{pH}\left(\right.$ dose $=1.0 \pm 0.2 \mathrm{~g} / \mathrm{L}, 10^{-3} \mathrm{M} \mathrm{KCl}$ as 418 electrolyte).

419

420 

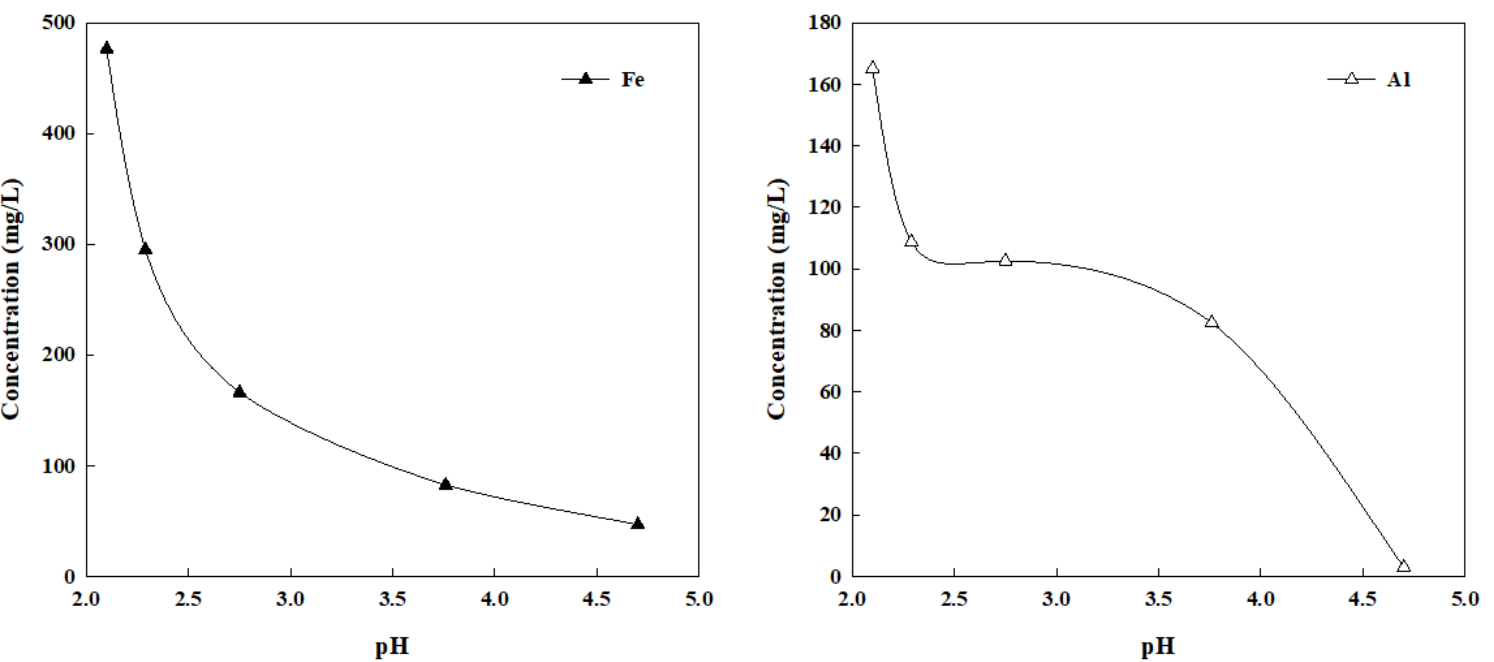

421
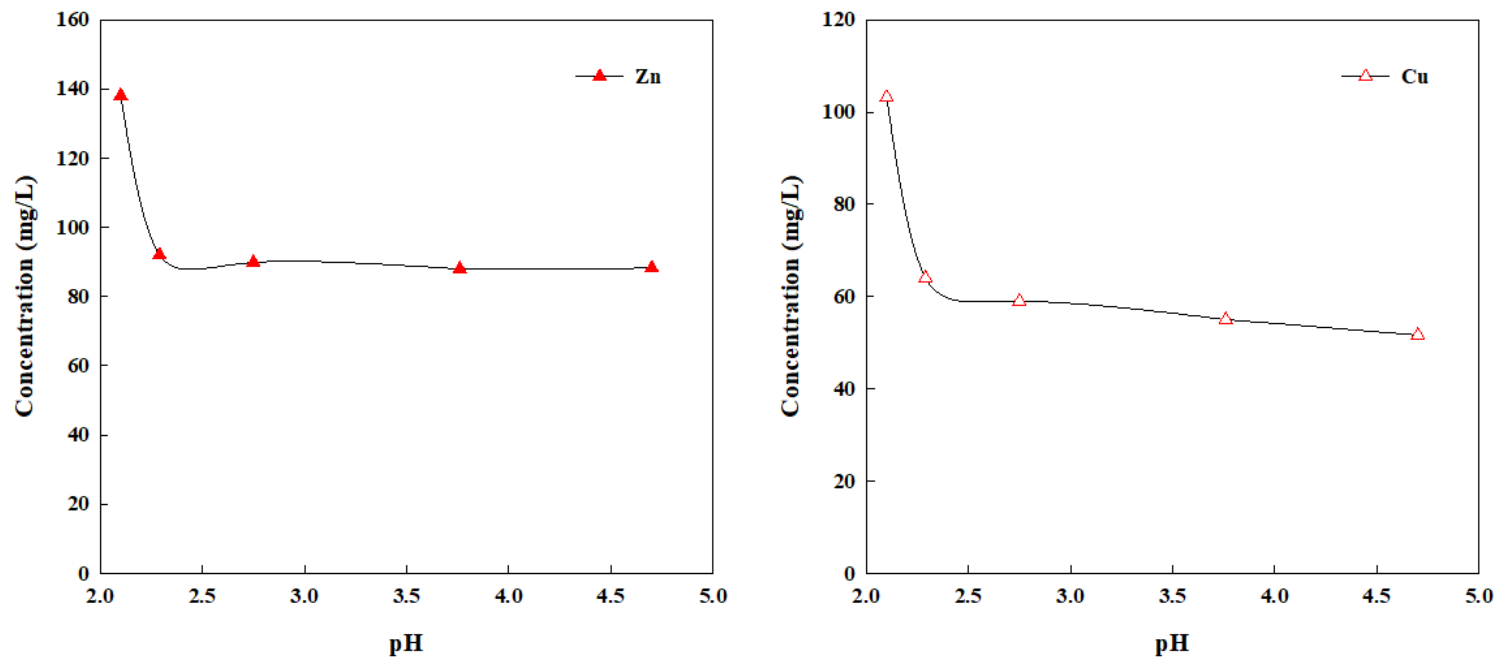

422

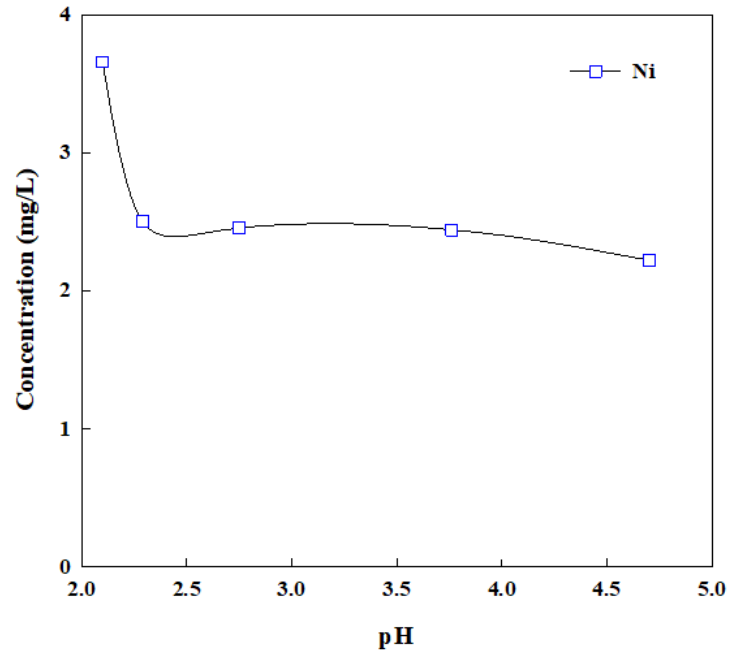

425 Fig. 6. Influence of $\mathrm{pH}$ on heavy metal removal from $\mathrm{AMD}$ solution with $500{ }^{\circ} \mathrm{C}$ heated 426 zeolite $($ dose $=10 \pm 0.2 \mathrm{~g} / \mathrm{L})$ 


\subsection{Performance of submerged DCMD}

428 The potential of achieving good quality water for reuse was evaluated using submerged DCMD.

430

\subsubsection{Permeate flux and quality}

432 An initial permeate flux of $2.5 \pm 0.2 \mathrm{LMH}$ was achieved (Choi et al., 2018) and the flux remained stable throughout the operation duration $(30 \mathrm{~h})$, enabling to achieve $50 \%$ water recovery (Fig. 7). The initial AMD solution (TDS of $6.4 \mathrm{~g} / \mathrm{L}$ ) was concentrated by 2 times (TDS of $12.9 \mathrm{~g} / \mathrm{L}$ ). Meanwhile, the concentration of permeate solution remained low (TDS significantly from $0.13 \mathrm{mg} / \mathrm{L}$ to $50 \mathrm{mg} / \mathrm{L}$.

\subsubsection{Membrane analysis}

Visible brown deposition (resembling iron oxides) was observed on the used membrane (Fig.

8b) compared to the virgin membrane (Fig. 8a). SEM-EDX analysis revealed Fe, $\mathrm{S}$ and $\mathrm{Al}$ deposition on the membrane. The presence of $\mathrm{Fe}$ and $\mathrm{Al}$ on the membrane could be attributed to the high precipitation affinity of these metals at increased concentration under thermal condition (Gryta, 2007). The precipitated metals predominantly deposited on the membrane surface and was loosely attached to the surface. It is likely that the deposition only partially blocked the membrane pores, and therefore, a stable permeate flux was maintained throughout the operation duration. Nevertheless, the contact angle of the used membrane $\left(68.6 \pm 0.8^{\circ}\right)$ reduced by $38-40 \%$ compared to the virgin membrane $\left(109.5 \pm 0.5^{\circ}\right)$, suggesting that the Fe deposition resulted in the reduction of membrane hydrophobicity and partial wetting of sulfate ions. 


\subsection{Performance of integrated submerged DCMD-sorption}

453

454

455

456

457

458

459

460

461

462

463

464

465

466

467

468

469

470

471

472

473

474

475

476

An integration of zeolite with submerged DCMD (Fig. 1) offers the potential for improving the performance of both processes in a single system. The integrated system enable zeolite to be used in fine powder form with long contact time (more than $24 \mathrm{~h}$ ) when kept suspended in a storage tank. In return, the heavy metal removal by $500{ }^{\circ} \mathrm{C}$ heat treated zeolite $($ dose $=10.0$ $\pm 0.2 \mathrm{~g} / \mathrm{L})$ at $\mathrm{pH} 4$ will ensure minimal $\mathrm{Fe}$ and $\mathrm{Al}$ deposition onto the membrane during the submerged DCMD process.

\subsubsection{Permeate flux and quality}

The integrated submerged DCMD-sorption system showed similar flux pattern as the submerged DCMD (Fig. 7), indicating that the DCMD performance was not affected by the presence of sorbent in the storage tank. The integrated system enabled to achieve high rejection of all ions, maintaining a permeate TDS of less than $0.01 \mathrm{~g} / \mathrm{L}$. The sulfate concentration in the feed solution was increased from $4.2 \mathrm{~g} / \mathrm{L}$ to around $8.2 \mathrm{~g} / \mathrm{L}$, while the sulfate concentration in the permeate solution remained low (less than $0.13-0.15 \mathrm{mg} / \mathrm{L}$ ).

\subsubsection{Membrane analysis}

The used membrane showed minimal Fe and Al depositions, according to the SEM-EDX analysis (Fig. 8c). The contact angle of the used membrane $\left(99.7 \pm 0.4^{\circ}\right)$ only reduced slightly by $10 \%$ compared to the virgin membrane $\left(109.5 \pm 0.5^{\circ}\right)$, suggesting that the membrane hydrophobicity was minimally affected. The membrane analysis established the stability of the membrane to be used to treat acidic AMD solution.

Overall, the results indicated the suitability of integrated submerged DCMD-sorption system for producing high quality water with simultaneous uptake of heavy metals by zeolite. The 


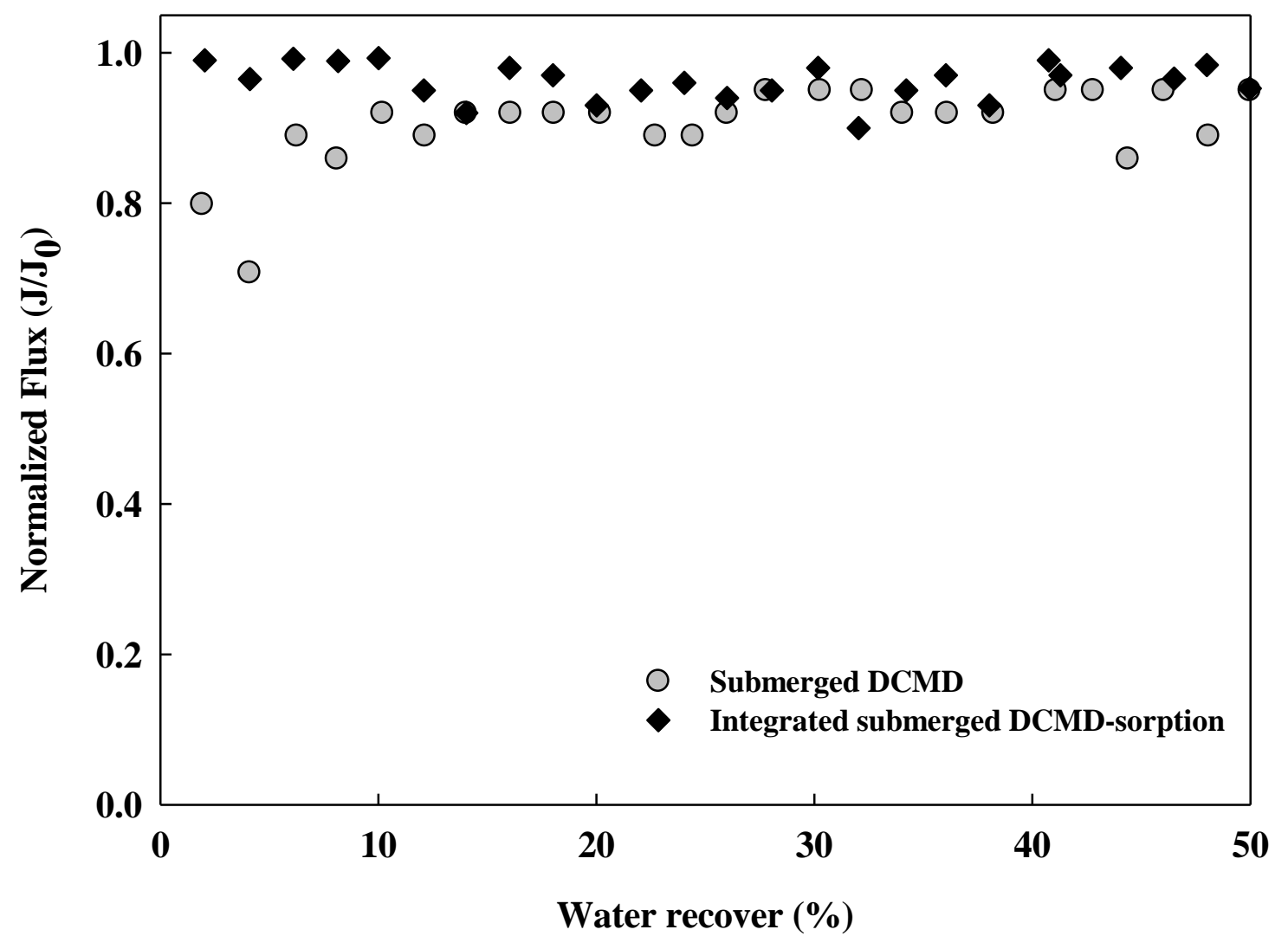

480 Fig. 7. Permeate flux for AMD treatment using submerged DCMD and integrated submerged

481 DCMD -sorption system

482

(a)

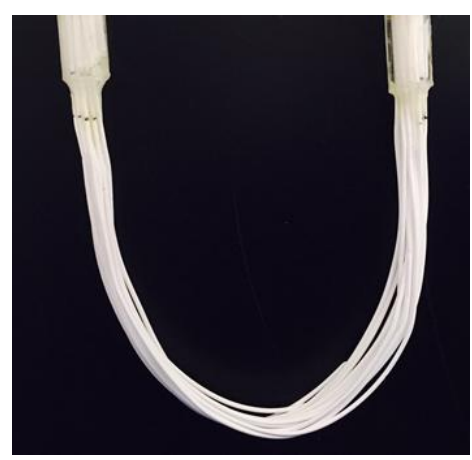

(b)

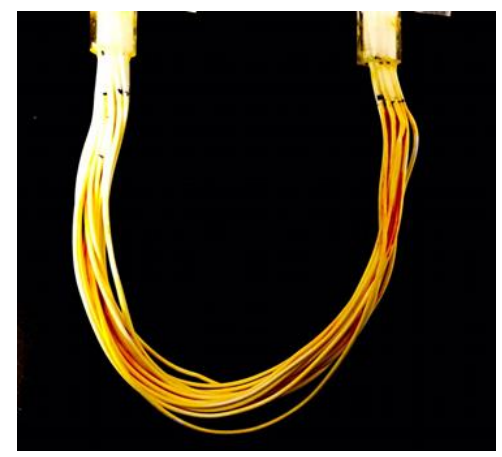

(c)

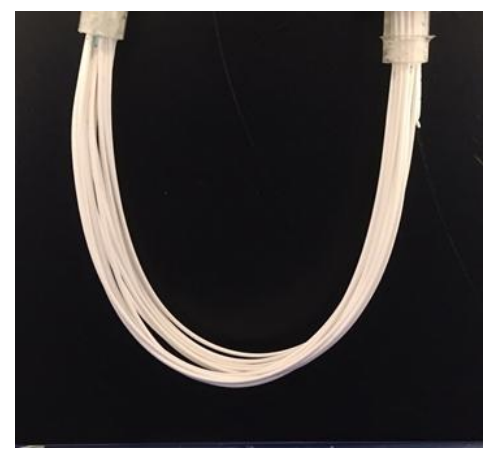



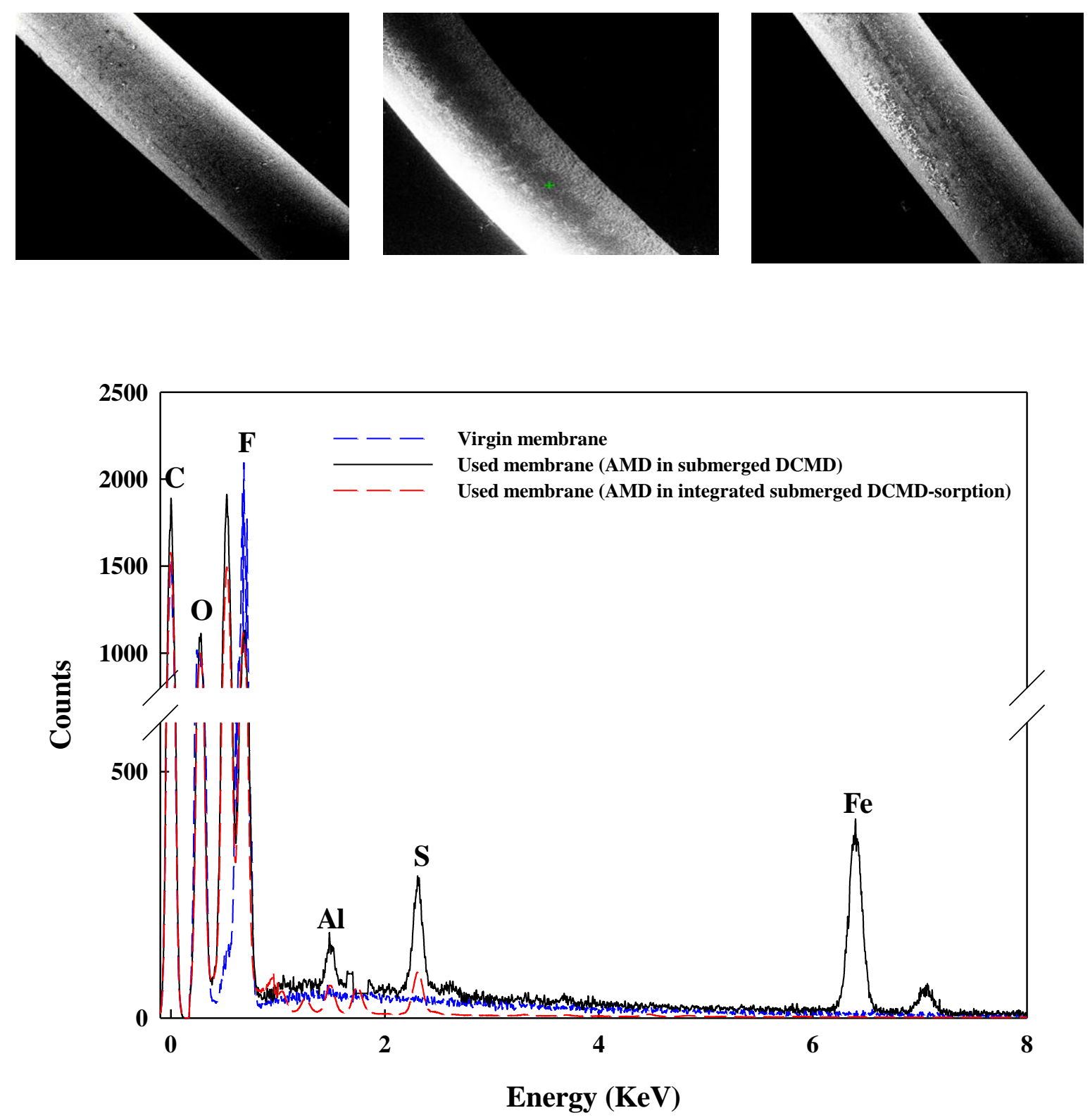

Fig. 8. SEM-EDX of hollowfiber membrane (a) virgin (b) used membrane with AMD in submerged DCMD (c) used membrane with AMD in integrated DCMD-sorption. 
487 An integrated submerged DCMD - zeolite sorption system for simultaneous removal of heavy metals and fresh water production from AMD was evaluated in this study. The results showed:

- A simple heat treatment was effective to increase the performance of natural zeolite for heavy metal removal from AMD solution. Heat treatment of natural zeolite at $500{ }^{\circ} \mathrm{C}$ enhanced heavy metal removal by $26-30 \%$.

- The removal affinity for heavy metal was in the order of $\mathrm{Fe}>\mathrm{Al}>\mathrm{Zn}>\mathrm{Cu}>\mathrm{Ni}$. The maximum sorption capacity (based on Langmuir $\mathrm{Q}_{\max }$ ) was 62.11, 44.64, 39.96, 36.10, 19.80 and $1.09 \mathrm{mg} / \mathrm{g}$ respectively.

- $\quad \mathrm{Fe}$ and $\mathrm{Al}$ removal was close to $100 \%$ with $500{ }^{\circ} \mathrm{C}$ heat treated zeolite while $38-40 \%$ of $\mathrm{Zn}, \mathrm{Cu}$ and $\mathrm{Ni}$ was achieved.

- $\quad$ Submerged DCMD enabled to treat AMD solution to achieve 50\% water recovery while maintaining a stable flux. Nevertheless, $\mathrm{Fe}$ and $\mathrm{Al}$ precipitation from concentrated AMD deposited onto the hollow fibre membrane. This reduced the membrane hydrophobicity and caused partial wetting of sulfate ions. valuable $\mathrm{Cu}, \mathrm{Ni}$ and $\mathrm{Zn}$ that can be recovered further. 
512 Acknowledgements

513 The authors acknowledge the support received for this study from University of Technology

514 Sydney's (UTS) Early Career Researcher Fund and Centre for Technology in Water and

515 Wastewater, UTS Early Career Researcher program and UTS chancellor's postdoctoral

516 research fellowship

517

518 
Aguiar, A.O., Andrade, L.H., Ricci, B.C., Pires, W.L., Miranda, G.A., Amaral, M.C.S., 2016. Gold acid mine drainage treatment by membrane separation processes: An evaluation of the main operational conditions. Sep. Purif. Technol. 170, 360-369. Akdeniz, Y., Ülkü, S., 2007. Microwave effect on ion-exchange and structure of clinoptilolite. J. Porous Mater. 14(1), 55-60.

525 Al-Haj, A.A., Ribhi, E.-B., 1997. Removal of Lead and Nickel Ions Using Zeolite Tuff. J. Chem. Technol. Biot. 69(1), 27-34.

527 Alvarez-Ayuso, E., Garcia-Sanchez, A., Querol, X., 2003. Purification of metal electroplating waste waters using zeolites. Water Res. 37(20), 4855-4862.

529 Ambiado, K., Bustos, C., Schwarz, A., Bórquez, R., 2017. Membrane technology applied to acid mine drainage from copper mining. Water Sci. Technol. 75, 705-715. An, W., Swenson, P., Wu, L., Waller, T., Ku, A., Kuznicki, S.M., 2011. Selective separation of hydrogen from $\mathrm{C}_{1} / \mathrm{C}_{2}$ hydrocarbons and $\mathrm{CO}_{2}$ through dense natural zeolite membranes. $\mathrm{J}$. Membr. Sci. 369(1-2), 414-419.

534 Caraballo, M.A., Rötting, T.S., Macías, F., Nieto, J.M., Ayora, C., 2009. Field multi-step 535 limestone and $\mathrm{MgO}$ passive system to treat acid mine drainage with high metal concentrations. Appl. Geochem. 24(12), 2301-2311.

537 Choi, Y., Naidu, G., Jeong, S., Lee, S., Vigneswaran, S., 2018. Fractional-submerged 538 membrane distillation crystallizer (F-SMDC) for treatment of high salinity solution. 539 Desalination 440, 59-67.

540 Choi, Y., Naidu, G., Jeong, S., Vigneswaran, S., Lee, S., Wang, R., Fane, A.G., 2017. 541 Experimental comparison of submerged membrane distillation configurations for 542 concentrated brine treatment. Desalination 420, 54-62. 
543 Contreras, J.O., Flores, D.P., Gutierrrez, P., Crooker, P.C., 2015. Acid Mine Drainage in

544 Chile: An Opportunity to Apply Bioremediation Technology. Hydrology Current Research $5456(3), 1-8$.

546 Englert, A.H., Rubio, J., 2005. Characterization and environmental application of a Chilean 547 natural zeolite. Int. J. Miner. Process. 75(1-2), 21-29.

548 Crane, R.A., Sapsford, D.J., 2018. Towards "Precision Mining" of wastewater: Selective recovery of $\mathrm{Cu}$ from acid mine drainage onto diatomite supported nanoscale zerovalent iron particles. Chemosphere 202, 339-348.

551 Fitzpatrick, R.W., Grealish, G., Shand, P., Simpson, S.L., Merry, R.H., Raven, M.D., 2009.

552 Acid sulfate soil assessment in Finniss River, Currency Creek, Black Swamp and Goolwa

553 Channel, South Australia. CSIRO land and water science report 26/09 CSIRO, Adelaide.

554 Gryta, M., 2007. Effect of iron oxides scaling on the MD process performance. Desalination 555 216(1-3), 88-102.

556

Kalin, M., Fyson, A., Wheeler, W.N., 2006. The chemistry of conventional and alternative

557 treatment systems for the neutralization of acid mine drainage. Sci. Total Environ. 366, 395-

558408.

559 Kesieme, U.K., Milne, N., Aral, H., Cheng, C.Y., Duke, M., 2012. Novel application of 560 membrane distillation for acid and water recovery from mining waste waters. International Mine Water Association Symposium 2012 Mine Water and the Environment, Curran 562 Associtates Inc., Bunbury, Australia.

563 Khayet, M., 2013. Solar desalination by membrane distillation: Dispersion in energy 564 consumption analysis and water production costs (a review). Desalination 308, 89-101. Marcello, R.R., Galato, S., Peterson, M., Riella, H.G., Bernardin, A.M., 2008. Inorganic 566 pigments made from the recycling of coal mine drainage treatment sludge. J. Environ. 567 Manage. 88(4), 1280-1284. 
Martí-Calatayud, M.C., Buzzi, D.C., García-Gabaldón, M., Ortega, E., Bernardes, A.M., Tenório, J.A.S., Pérez-Herranz, V., 2014. Sulfuric acid recovery from acid mine drainage by means of electrodialysis. Desalination 343, 120-127.

Mondale, K.D., Carland, R.M., Aplan, F.F., 1995. The comparative ion exchange capacities of natural sedimentary and synthetic zeolites. Miner. Eng. 8(4), 535-548.

Moreno, N., Querol, X., Ayora, C., Pereira, C.F., Janssen-Jurkovicová, M., 2001. Utilization of Zeolites Synthesized from Coal Fly Ash for the Purification of Acid Mine Waters. Environ. Sci. Technol. 35(17), 3526-3534.

Mosley, L.M., Biswas, T.K., Dang, T., Palmer, D., Cummings, C., Daly, R., Simpson, S., Kirby, J., 2018. Fate and dynamics of metal precipitates arising from acid drainage discharges to a river system. Chemosphere 212, 811-820.

Motsi, T., Rowson, N.A., Simmons, M.J.H., 2009. Adsorption of heavy metals from acid mine drainage by natural zeolite. Int. J. Miner. Process. 92(1-2), 42-48.

Naidu, G., Jeong, S., Choi, Y., Jang, E., Hwang, T.-M., Vigneswaran, S., 2014. Application of vacuum membrane distillation for small scale drinking water production. Desalination 354, 53-61.

Naidu, G., Jeong, S., Choi, Y., Song, M.H., Oyunchuluun, U., Vigneswaran, S., 2018. Valuable rubidium extraction from potassium reduced seawater brine. J. Clean. Prod. 174, 1079-1088.

Naidu, G., Jeong, S., Choi, Y., Vigneswaran, S., 2017. Membrane distillation for wastewater reverse osmosis concentrate treatment with water reuse potential. J. Membr. Sci. 524, 565575.

Nguyen, T.C., Loganathan, P., Nguyen, T.V., Vigneswaran, S., Kandasamy, J., Naidu, R., 2015. Simultaneous adsorption of $\mathrm{Cd}, \mathrm{Cr}, \mathrm{Cu}, \mathrm{Pb}$, and $\mathrm{Zn}$ by an iron-coated Australian zeolite in batch and fixed-bed column studies. Chem. Eng. J. 270, 393-404. 
Parbhakar-Fox, A.K., Edraki, M., Hardie, K., Kadletz, O., Hall, T., 2014. Identification of acid rock drainage sources through mesotextural classification at abandoned mines of Croydon, Australia: Implications for the rehabilitation of waste rock repositories. J. Geochem. Explor. 137, 11-28.

601

Qiu, W., Zheng, Y., 2009. Removal of lead, copper, nickel, cobalt, and zinc from water by a

602

603

604

605

606

607

608

609

610

611

612

613

614

615

616 cancrinite-type zeolite synthesized from fly ash. Chem. Eng. J. 145(3), 483-488.

Rios, C.A., Williams, C.D., Roberts, C.L., 2008. Removal of heavy metals from acid mine drainage (AMD) using coal fly ash, natural clinker and synthetic zeolites. J. Hazard. Mater. $156(1-3), 23-35$.

Santiago, O., Walsh, K., Kele, B., Gardner, E., Chapman, J., 2016. Novel pre-treatment of zeolite materials for the removal of sodium ions: potential materials for coal seam gas coproduced wastewater. Springerplus 5, 571.

Sprynskyy, M., Buszewski, B., Terzyk, A.P., Namiesnik, J., 2006. Study of the selection mechanism of heavy metal $\left(\mathrm{Pb}^{2+}, \mathrm{Cu}^{2+}, \mathrm{Ni}^{2+}\right.$, and $\left.\mathrm{Cd}^{2+}\right)$ adsorption on clinoptilolite. J. Colloid Interface Sci. 304(1), 21-28.

Taffarel, S.R., Rubio, J., 2010. Adsorption of sodium dodecyl benzene sulfonate from aqueous solution using a modified natural zeolite with CTAB. Miner. Eng. 23(10), 771-779.

Tolonen, E.-T., Sarpola, A., Hu, T., Rämö, J., Lassi, U., 2014. Acid mine drainage treatment using by-products from quicklime manufacturing as neutralization chemicals. Chemosphere $117,419-424$. 
Tomaszewska, M., Gryta, M., Morawski, A.W., 2001. Recovery of hydrochloric acid from metal pickling solutions by membrane distillation. Sep. Purif. Technol. 22-23, 591-600. Tomaszewska, M., Mientka, A., 2009. Separation of $\mathrm{HCl}$ from $\mathrm{HCl}-\mathrm{H}_{2} \mathrm{SO}_{4}$ solutions by membrane distillation. Desalination 240(1), 244-250.

Turner, M.D., Laurence, R.L., Conner, W.C., Yngvesson, K.S., 2000. Microwave radiation's influence on sorption and competitive sorption in zeolites. AlChE J. 46(4), 758-768.

Unger, C., Lechner, A.M., Glenn, V., Edraki, M., Mulligan, D.R., 2012. Mapping and Prioritising Rehabilitation of Abandoned Mines in Australia. Proceedings Life of mine conference, Brisbane, QLD, 259-265.

Vasquez, Y., Escobar, M.C., Neculita, C.M., Arbeli, Z., Roldan, F., 2016. Biochemical passive reactors for treatment of acid mine drainage: Effect of hydraulic retention time on changes in efficiency, composition of reactive mixture, and microbial activity. Chemosphere $153,244-253$.

Vital, B., Bartacek, J., Ortega-Bravo, J.C., Jeison, D., 2018. Treatment of acid mine drainage by forward osmosis: Heavy metal rejection and reverse flux of draw solution constituents. Chem. Eng. J. 332, 85-91.

Wingenfelder, U., Hansen, C., Furrer, G., Schulin, R., 2005. Removal of Heavy Metals from Mine Waters by Natural Zeolites. Environ. Sci. Technol. 39(12), 4606-4613.

Yao, M., Woo, Y.C., Tijing, L.D., Choi, J.-S., Shon, H.K., 2018. Effects of volatile organic compounds on water recovery from produced water via vacuum membrane distillation. Desalination 440, 146-155.

Zhang, M., 2011. Adsorption study of $\mathrm{Pb}(\mathrm{II}), \mathrm{Cu}(\mathrm{II})$ and $\mathrm{Zn}$ (II) from simulated acid mine drainage using dairy manure compost. Chem. Eng. J. 172(1), 361-368. 
Supplementary Material
Click here to download Supplementary Material: Supplementary document.doc

Supplementary Material
Click here to download Supplementary Material: Supplementary document.doc

\begin{abstract}
che here to download Supplementary Material: Supplementary document.doc
\end{abstract}

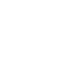

$\sqrt{10}$

$\sqrt{3}$

$\sqrt{2}$

(1)

(1)

(1)

(1) ronger $x^{2}$ . . .

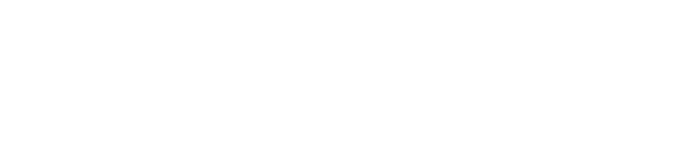
$\left(\frac{10}{10}\right.$ $\left(\frac{10}{10}\right.$ $\left(\frac{10}{10}\right.$ $\left(\frac{10}{10}\right.$ $\left(\frac{10}{10}\right.$ $\left(\frac{10}{10}\right.$ $\left(\frac{10}{10}\right.$ 